Natalia Siwik

Uniwersytet Ekonomiczny w Krakowie

natka.siwik@gmail.com

\title{
Zarządzanie ryzykiem i zarządzanie kryzysowe w kontekście upadku legendarnego biura podróży Thomas Cook
}

\section{Streszczenie}

Upadek najstarszego biura podróży Thomas Cook rozszedł się szerokim echem na całym świecie. Chociaż od tego wydarzenia minął rok, kwestia ta wciąż wydaje się aktualna, a przyczyny upadku firmy dalej są dyskutowane. Obok czynników finansowych, pogodowych i społecznych wymienia się brak przygotowania biura i niewłaściwe zarządzanie. Celem rozdziału jest przybliżenie błędów firmy Thomas Cook oraz podkreślenie ważności relacji, więzi, zarządzania kryzysowego i zarządzania ryzykiem. W pracy wykorzystano kwerendę literatury oraz analizę netograficzną, a wyniki badań wskazały na bezpośredni powód upadku biura, czyli jego stagnację i powierzchowne więzi bez zabezpieczenia w zarządzaniu. W ramach wniosków podkreślono ważne składowe postępowania w zarządzaniu i relacjach biura podróży, co może się okazać podstawą przyszłych badań.

\section{Wprowadzenie}

Zarządzanie kryzysowe oraz zarządzanie ryzykiem to bardzo szerokie pojęcia, wiążące się z wieloma dziedzinami. Od 2000 r. wciąż pojawiają się kolejne prace opisujące powyższe zagadnienia. Ich liczba zależna jest głównie od obecnej sytuacji (chociażby gospodarczej), czego dowodem jest mnogość wyników dla frazy „zarządzanie ryzykiem” w Google Scholar. Chociaż oba zagadnienia są zauważane i ciągle badane, wiele przedsiębiorstw wciąż bagatelizuje znaczenie wcześniejszego przygotowania na sytuacje kryzysowe oraz odczytywania sygnałów alarmowych płynących z otoczenia, czego przykładem jest upadłe biuro podróży Thomas Cook. Nadal brakuje oficjalnych opisów powyższego procesu oraz publikacji 
badaczy, jednakże można zauważyć pewne luki i poważne zaniedbania w zarządzaniu kryzysowym i zarządzaniu ryzykiem (przyczyny upadku firmy Thomas Cook wynikają bezpośrednio $z$ wadliwego zarządzania). Żeby jednak dobrze to zrozumieć, $\mathrm{w}$ pierwszej części zdefiniowano powyższe pojęcia w oparciu o każde przedsiębiorstwo, a dopiero $\mathrm{w}$ drugiej postawiono pytanie, czy błędne zarządzanie tym biurem podróży faktycznie miało wpływ na jego upadek.

\section{Przegląd literatury}

\section{Ogólne pojęcie zarządzania kryzysowego i zarządzania ryzykiem}

Zarządzanie kryzysowe i zarządzanie ryzykiem, chociaż mają ze sobą wiele wspólnego, są odrębnymi zagadnieniami. Pierwsze powiązane jest ze słowem „kryzys”, a ten według „Encyklopedii zarządzania” jest jedną z czterech faz cyklu koniunkturalnego, który obrazuje krzywą wahań w gospodarce. Jego przyczyn można szukać zarówno poza systemem gospodarczym (w wojnach lub odkryciach geograficznych), jak i zakładając, że każdy rozkwit owocuje załamaniem i odwrotnie (Urbanik i Dudkiewicz). W znaczeniu ogólnym kryzys jest okresem przesilenia, przełomu. Zarządzanie kryzysem z kolei jest radzeniem sobie z nim w ramach przepisów prawnych. Oprócz zasad, źródeł i zakresów wyróżnione zostały cztery fazy cyklu zarządzania kryzysowego (Wróblewski, 2014). Pierwszą jest zapobieganie jeszcze przed wystąpieniem wydarzenia, co wiąże się z redukcją ryzyka. Jako drugą fazę wyróżniono przygotowanie się, którego owocem są plany reagowania kryzysowego. Kolejno wymieniono reagowanie po wystąieniu zagrożenia, do którego potrzebne jest jednak jego wcześniejsze wykrycie, oraz odbudowę, czyli przywrócenie stanu sprzed kryzysu, co wiąże się ściśle z pojęciem organizacji uczącej się. Cały cykl powinny poprzedzać systemy wczesnego ostrzegania (SWO), bowiem służą one do identyfikacji wszelkich zakłóceń jeszcze przed wystąpieniem realnego zagrożenia. Jak podaje Stabryła (2018), SWO obserwowane są każdego dnia, chociażby w przyrodzie lub w wojsku. Powyższe fakty to jedynie podstawy bardzo złożonego zagadnienia, które wymaga doprecyzowania i bardziej szczegółowego określenia, czego regres dotyczy. Podobnie jest z definiowaniem ryzyka - na różne aspekty zwracają uwagę badacze kolejnych dziedzin, od ekonomii i prawa po przyrodę, hazard oraz gry. Najkrócej można je opisać jako prawdopodobieństwo wystąpienia strat będących efektami decyzji ekonomicznych (Czerwonka i in.), co wiąże się z upływem dłuższego czasu. W zarządzaniu nim powstała formuła, a dokładnie zbiór działań opisujących właściwe zachowanie $\mathrm{w}$ przypadku pojawienia się ryzyka, jednocześnie będące jego czterema podstawowymi funkcjami. Są to kolejno: identyfikacja (źródeł ryzyka, zdarzeń oraz sygnałów), pięcioetapowa analiza, projektowanie reakcji na ryzyko oraz monitorowanie go (Stabryła, 2018).

Z powyższego zestawienia obu zagadnień można zatem wysunąć tezę, że istnieją pewne podobieństwa między fazami cyklu zarządzania kryzysowego oraz zbiorem działań w zarządzaniu ryzykiem. Oba procesy są bardzo złożone 
i wieloaspektowe, jednocześnie wymagające od strony podażowej oraz biur podróży wysiłku, wcześniejszego przygotowania, prognozowania, czujności oraz wrażliwości na obecną sytuację. Obok zarządzania kryzysowego i zarządzania ryzykiem powinno się omówić jeszcze inne elementy, takie jak zarządzanie strategiczne, drzewo celów, hierarchia, wiedza, zaufanie, głębsze SWO, więzi i zależności oraz błędy w komunikacji. Jednakże są to kwestie bardzo szerokie, a wymienione definicje i narzędzia są wystarczające do omówienia błędów, jakie popełniło biuro podróży Thomas Cook w ostatnich latach swojej działalności.

\section{Metodyka badań}

Na firmie Thomas Cook, tak jak na każdym biurze podróży, spoczywa albo spoczywała zawsze duża odpowiedzialność i wiele zobowiązań. Kwestie te wymagają od przedsiębiorstw bardzo dobrej organizacji. Podobnie jest z zarządzaniem w kryzysie i zarządzaniem ryzykiem - oba zagadnienia powinny być w biurach wysoko rozwinięte, zwłaszcza że turystyka jest bardzo wrażliwa i narażona na wszelkie zmiany (chociażby pogody oraz chęci kupujących). Żeby jednak dobrze zobrazować znaczenie powyższych kwestii, autorka przeprowadziła przegląd artykułów, reportaży, wykresów oraz danych, którego wyniki mogą posłużyć do dalszych badań.

\section{Wyniki badań}

\section{Pierwszy kryzys biura podróży w okresie 2007-2012}

W kryzysie, jaki spotkał 178-letnie biuro podróży, potrzebne było dobre zarządzanie kryzysowe, a także wcześnie wszczęte zarządzanie ryzykiem i SWO. Na zagadnienia te w firmie Thomas Cook zwrócono uwagę, jednakże było już za późno na wdrażanie planu ratunkowego. Analizę powyższych procesów w tym biurze podróży należy zacząć od roku 2007, bowiem już wtedy powinny zostać dostrzeżone sygnały alarmowe otoczenia i podjęte konkretne działania (szczególnie że ryzyko rozpatrywane jest w długim okresie). Trudno powiedzieć, czy Thomas Cook brał pod uwagę fazy cyklu zarządzania kryzysowego oraz zarządzanie ryzykiem - prawdopodobnie już na zawsze pozostanie to sekretem przedsiębiorstwa. Przed 2007 r. biuro rozwijało się jednak prawidłowo - kontynuowało wspaniałą spuściznę, miało wielu lojalnych klientów i stale się przekształcało, chociażby z Thomas Cook \& Son na Thomas Cook AG w 2001 r. (Thomas Cook Group plc, 2007). Co więcej, firma sprzedawała swoje spółki oraz kupowała kolejne - do 2007 r. Thomas Cook AG posiadał biura o tej samej nazwie w wielu krajach Europy i w Chinach, Neckermanna w Polsce, w Czechach i na Węgrzech, Neckermanna Reisen w Austrii oraz Szwajcarii, a także linię lotniczą Condor (Thomas Cook Group plc, 2007). W tym też roku Thomas Cook AG połączył się z kolejnym globalnym zespołem, grupą MyTravel, zmieniając nazwę na Thomas 
Cook Group plc. Decyzja ta miała w przyszłości przynieść fatalne skutki, bowiem w skład grupy MyTravel wchodziły kolejne dwie linie lotnicze, skandynawskie biura podróży Ving, Tjæreborg i Spies oraz kanadyjskie ALBA Tours i Sunquest Vacations (Thomas Cook Group plc, 2007). Cała inicjatywa była bardzo kosztowna - żeby ją sfinalizować, firma Thomas Cook wzięła kredyt o wysokości 1,7 mld funtów. Obliczono, że dla spłaty samych odsetek biuro musiałoby sprzedawać 3 mln wycieczek rocznie (CNBC, 2019). Celem transakcji był plan zaoszczędzenia 75 mln funtów rocznie, jednakże Thomas Cook naraził się tym samym na zbyt duże ryzyko, bowiem połączenie grup zbiegło się $\mathrm{w}$ czasie $\mathrm{z}$ początkami kryzysu finansowego na świecie z lat 2007-2009 (Holzer, 2009) oraz z późniejszym regresem gospodarczym 2011-2012 (Forbes, 2012). Mimo trudniejszego okresu i dużego ryzyka (nie wiadomo, czy biuro korzystało wtedy z funkcji zarządzania ryzykiem) przedsiębiorstwo przeprowadzało kolejne transakcje, przyłączając do grupy niemiecką spółkę Öger Tours (2010), rosyjskie Intourist (2011) oraz bułgarskie Astral Holidays (2013). W 2011 r. oraz 2012 r. pojawiło się realne zagrożenie, które powinno było zostać wykryte już wcześniej przez SWO (jeśli Thomas Cook takowych systemów używał). Lata te były okresem, kiedy analitycy zaczęli podważać przyszłość biura, głównie przez kolejne kredyty zaciągane $\mathrm{w}$ bardzo krótkich odstępach czasu. Można uznać, że były to pierwsze sygnały alarmowe z otoczenia. Co więcej, ze swojego stanowiska zrezygnował ówczesny prezes biura, spadła również wartość akcji o 75\% (Scuffham, 2011). Wobec kryzysu firmy wypowiedział się chociażby analityk Espirito Santo Geetanjani Sharma (który przewidywał brak płaszcza dla biura od banków) oraz były prezes Manny Fontenla-Novoa (potwierdził spadek notowań), o czym również wspomina Scuffham (2011). Przywołuje on także optymistyczną wypowiedź dyrektora naczelnego firmy Thomas Cook Sama Weihagena, który nie widział zagrożenia, uważał biuro podróży za silne przedsiębiorstwo, a odpowiedzialnością obarczył problemy globalne. Analizując powyższe decyzje firmy oraz ówczesną sytuację na świecie, można wysunąć kilka wniosków. Po pierwsze, Thomas Cook nie powinien szukać przyczyny regresu jedynie $\mathrm{w}$ otoczeniu zewnętrznym, ale także $\mathrm{w}$ wewnętrznym (czyli w zarządzaniu). Co więcej, zaciąganie kolejnych kredytów jest posunięciem bardzo gwałtownym, podjętym prawdopodobnie bez wcześniejszej analizy zarządzania ryzykiem. Należy także zauważyć, że gdyby nie pożyczkodawcy, Thomas Cook zbankrutowałby już w 2012 r., z czego biuro podróży również powinno wyciągnąć wnioski, chociażby w ramach ostatniej fazy zarządzania kryzysowego, jaką jest odbudowa i uczenie się przedsiębiorstwa. Oprócz tego touroperator pokładał złudne nadzieje w swoich spółkach spoza Wielkiej Brytanii, zapominając, że sytuacja w spółce matce jest kluczowa dla przetrwania spółek córek. Z powyższej refleksji można więc wywnioskować, że w latach 2007-2012 w biurze podróży Thomas Cook brakowało prawidłowego i skutecznego zarządzania w kryzysie oraz zarządzania ryzykiem. Wspomniane procedury powinny być przeprowadzone nawet po czasie, bowiem uchroniłoby to przedsiębiorstwo przed kolejnym kryzysem w 2019 r. Oprócz korzyści dla firmy, powyższe działania są po prostu uczciwe wobec interesariuszy, akcjonariuszy i otoczenia, bowiem każde z wymienionych może dotknąć regres $\mathrm{w}$ następstwie kryzysu w biurze, z którym łączą 
je więzi i relacje. Kryzys wywołuje fatalne skutki, chociażby w trzech sferach: finansowej, bezpieczeństwa publicznego, a nawet może skutkować utratą życia (Coombs, 2007). Żeby temu zapobiec, powstał kolejny podział w procesie zarządzania kryzysem, składający się z trzech faz: pre-crisis (przed), crisis response (odpowiedź na kryzys) oraz post-crisis (po), o czym również wspomina Coombs (2007). Powyższy cykl jest bardzo podobny do czterech faz zarządzania kryzysowego, jednakże w ramach trzyczęściowego procesu dokładnie wyszczególniono: stworzenie złożonego planu zarządzania kryzysowego (CMP), utrzymanie relacji $z$ otoczeniem, szybką, dokładną oraz logiczną reakcję, a także odbudowę wizerunku, relacji i samej firmy (Coombs, 2007). Ważne jest również współczucie dla poszkodowanych. Odnosząc podaną procedurę do działań biura podróży Thomas Cook, można wyciągnąć wnioski, że zarządzanie kryzysowe i zarządzanie ryzykiem w tej firmie nie istniały albo były nieskuteczne. Należy jednak pamiętać, że do wiadomości publicznej nie trafiły dokładne dane na ten temat, co mogło być rodzajem strategii, jednakże wciąż powinno zapewniać bezpieczeństwo publiczne. O nieskuteczności zarządzania kryzysowego i zarządzania ryzykiem w Thomas Cook świadczą też decyzje podjęte w latach 2013-2019.

\section{Działalność biura podróży Thomas Cook w latach 2013-2019, drugi kryzys i upadek firmy}

Kryzys przedsiębiorstwa Thomas Cook z 2012 r. wydawał się względnie zażegnany. W 2014 r. ze swojego stanowiska zrezygnowała jednak nowa dyrektor generalna biura, Harriet Green, co wiązało się ze spadkiem wartości akcji o $350 \mathrm{mln}$ funtów (Thomas, 2014). Co więcej, wciąż żywa była ekspozycja firmy na ryzyko kredytowe. W latach 2013-2019 zmniejszyła się również objętość raportów wydanych przez biuro podróży w I kwartale roku za październik, listopad i grudzień roku poprzedniego w porównaniu do jego konkurentów. Co więcej, firma całkowicie zrezygnowała z prezentacji w 2018 r. i 2019 r. (Zespół Instytutu Badań Rynku Turystycznego TravelDATA i www.wczasopedia.pl, 2019). Fakt ten mógł świadczyć o słabnącej komunikacji między firmą Thomas Cook a otoczeniem, czym firma naraziła się na ryzyko utraty zaufania w przyszłości. Należy jednak pamiętać, że jest to tylko subiektywny wniosek, bowiem przyczyny mniejszej liczby stron $\mathrm{w}$ raportach i relacje $z$ udziałowcami w tym okresie pozostaną sekretem firmy. We wspomnianym czasie, a dokładnie po incydencie z 2015 r., spadła także lojalność klientów, kiedy ponownie wszczęto postępowanie sądowe po śmierci dwójki dzieci Shepard na wakacjach $\mathrm{z}$ biurem Thomas Cook (spowodowanej zatruciem tlenkiem węgla). Biuro podróży otrzymało wtedy $3 \mathrm{mln}$ funtów (od hotelu, w którym wydarzyła się tragedia), które bez porozumienia z rodzicami dzieci przekazało na rzecz UNICEF (Brinded, 2015). Posunięcie to skutkowało utratą klientów i spadkiem wartości akcji o 4\%. Firmie wytknięto także brak bezpośrednich przeprosin i brak ludzkiego współczucia, a jej działania nazwane zostały „chwyceniem pokrzywy" (Media First, 2015), co wiąże się również z błędnym zarządzaniem sławą. W kolejnych latach sytuacja się nie poprawiła - od października 2018 r. 
stopniowo zaczęła spadać wartość obligacji, co przedstawił Rosik (2019). W tym samym czasie notowano drastyczny spadek cen akcji - porównano zyski dla 2010 i 2018 r. oraz potwierdzono stratę w wysokości 1,5 mld funtów w maju 2019 r. (Mallinson, 2019). Powyższe kwestie skłoniły Thomas Cook do wdrożenia planu ratunkowego i zaawansowanych rozmów z udziałowcami i pożyczkodawcami, a w szczególności z chińską spółką Fosun. Planowano też restrukturyzację firmy. Rozmowy z instytucjami finansowymi nie doszły jednak do skutku, bowiem zażądano od biura $250 \mathrm{mln}$ dolarów na początek (Rosik, 2019). Powyższa kwestia oraz wiele innych czynników finansowych, społecznych, pogodowych, politycznych (Florencka, 2019), a także złudne skupienie na lojalności klientów, spadek wartości akcji, fala upałów, spadek wartości funta oraz skłonność Brytyjczyków do oszczędzania spowodowały, że w nocy z 22 na 23 września 2019 r. Thomas Cook ogłosił niewypłacalność. Upadek firmy skomentował prezes grupy TUI Friedrich Joussen, który podkreślił, że przez stagnację i niczym niewyróżniającą się ofertę Thomas Cook zmuszony był konkurować z biurami podróży w Internecie oraz z tanimi liniami lotniczymi (German, 2019). Podobne przemyślenia można wyczytać w komentarzu Tima Jeansa, szefa lotniska, który ocenił, że upadła firma realizowała „analogowy model biznesowy w cyfrowym świecie” (Florencka, 2019), a więc przysłowiowe „spoczywanie na laurach”. W decyzjach Thomas Cook w latach 2013-2019, tak jak w latach 2007-2012 można zauważyć, że biuro wciąż błędnie zarządzało kryzysem, a podejmowane przez nie ryzyko było zbyt duże i wiązało się z brakiem głębszej refleksji. Mimo wszystko Thomas Cook nawet po swoim upadku dalej obarczał winą pożyczkodawców, którzy ponoć nie wsparli planu ratunkowego. Inaczej upadek biura postrzegają pracownicy, którzy stawiają zarządzanie Thomas Cook w niekorzystnym świetle - zarzucali oni touroperatorowi złe kierowanie, a także brak strategii i celów (Glassdoor). Nie był to jedyny sygnał ostrzegawczy z otoczenia, biorąc pod uwagę również wcześniej wymienione opinie analityków, prezesa TUI, szefa lotniska oraz treść wielu stron internetowych - przykładem może być „Infinite Global”, na której opisano Petera Frankhausera (prezesa biura podróży w momencie jego upadku) obarczającego winą otoczenie (Barrett, Taylor, 2019). Podobne błędy w komunikacji cechowały decyzje firmy Thomas Cook już kilka lat wcześniej. Powyższe dane wskazują tym samym na zaniedbania biura podróży zarówno w komunikacji z otoczeniem, jak i w zarządzaniu ryzykiem i zarządzaniu w kryzysie.

\section{Zakończenie}

Upadek biura podróży Thomas Cook miał miejsce ponad rok temu, jednakże wciąż brakuje głębszych wniosków, badań oraz analiz tego tematu, które odpowiedziałyby na wiele pytań $i$ były przestrogą dla innych przedsiębiorstw $z$ tego sektora gospodarczego. Każdy z opisanych $w$ rozdziale elementów (zarządzanie kryzysowe, zarządzanie ryzykiem, otoczenie oraz więzi) jest ważną kwestią w zarządzaniu każdym przedsiębiorstwem. Brak prawidłowych nawyków w firmie Thomas Cook bezpośrednio przyczynił się do jej upadku, z kolei wadliwe zarządzanie było 
prawdopodobnie głównym powodem, dla którego touroperator musiał ogłosić niewypłacalność. Na upadek 178-letniego biura podróży składa się znacznie więcej przyczyn, jednakże wszystkie błędy, które popełnił Thomas Cook (zaciągnięcie wielu kredytów, obarczanie winą otoczenia, błędne wybory oraz zbyt późne wszczęcie procedury ratowania firmy), wiążą się z początkowymi decyzjami biura w zarządzaniu ryzykiem i zarządzaniu kryzysowym jeszcze w 2007 r. Być może gdyby Thomas Cook nie połączył się z grupą MyTravel, wciąż by istniał.

\section{Literatura}

Barrett P., Taylor M. (2019). Crisis and reputation management in the fallout from the Thomas Cook collapse (www.infiniteglobal.com; dostęp: 28.12.2020).

Brinded L. (2015). Thomas Cook's Facebook page is filling up with outraged comments over a $£ 3$ million payment the company received for the death of two children at one of its hotels (www.businessinsider.com; dostęp: 28.12.2020).

Coombs W.T. (2007). Crisis Management and Communications (www instituteforpr.org; dostęp: 28.12.2020).

CNBC (2019). British travel firm Thomas Cook collapses, stranding 600,000 people abroad (www.cmbc.com; dostęp: 27.12.2020).

Czerwonka K., Cież M., Kowal M. Ryzyko (www.mfiles.pl; dostęp: 26.12.2020).

Florencka K. (2019). Eksperci o powodach upadku Thomas Cook. „Analogowy biznes w cyfrowym świecie" (www.innpoland.pl; dostęp: 28.12.2020).

Forbes (2012). Spowolnienie w 2012 gorsze od kryzysu finansowego (www.forbes.pl; dostęp: 26.12.2020).

German M. (2019). Szef TUI: Thomas Cook upadł, bo się nie wyróżniał (www.turystyka. rp.pl; dostęp: 28.12.2020).

Glassdoor. Thomas Cook Reviews (www.glassdoor.com; dostęp: 28.12.2020).

Holzer R. (2009). Jak rozwijał się kryzys 2007-2009 - infografika, kalendarium (www. obserwatorfinansowy.pl; dostęp: 26.12.2020).

Mallinson H. (2019). Thomas Cook collapse: Now TUI cancels flights for customers after holiday firm collapse (www.express.co.uk; dostęp: 28.12.2020).

Media First (2015). Thomas Cook - a textbook case of how not to handle a crisis (www. mediafirst.co.uk; dostęp: 28.12.2020).

Rosik P. (2019). Upadło najstarsze biuro podróży na świecie Thomas Cook. To ważne ostrzeżenie dla inwestorów (www.strefainwestorow.pl; dostęp: 28.12.2020)

Scuffham M. (2011). Thomas Cook shares crash after default warning (www.reuters.com; dostęp: 27.12.2020).

Stabryła A. (red.) (2018). Podstawy organizacji i zarządzania. Podejścia i koncepcje badawcze. Wydawnictwo Uniwersytetu Ekonomicznego w Krakowie, Kraków, s. 33-35, 128, 142.

Thomas Cook Group plc. (2007). Annual Report \& Accounts (www.annualreports.com; dostęp: 27.12.2020).

Thomas N. (2014). More than £350m wiped off Thomas Cook after chief Harriet Green steps down (www.telegraph.co.uk; dostęp: 27.12.2020).

Urbanik G., Dudkiewicz A. Kryzys (www.mfiles.pl; dostęp: 26.12.2020). 
Wróblewski D. (red.) (2014). Zagadnienia ogólne z zakresu zarządzania ryzykiem i zarządzania kryzysowego. Analiza wybranych przepisów. Wydawnictwo CNBOP-PIB, Józefów, s. 13-14, 20.

Zespół Instytutu Badań Rynku Turystycznego TravelDATA i www.wczasopedia.pl. (2019). Analiza informacji mających wpływ na branżę turystyczną. Nastroje konsumenckie mocno psują biznes organizatorom i agentom... (www.wczasopedia.pl; dostęp: 28.12.2020).

\section{Risk management and crisis management in the context of the fall of the legendary travel agency Thomas Cook}

The fall of the oldest tourist agency 'Thomas Cook' spread loudly all over the world. Although a year has passed since this event, the issue still seems to be up-to-date, and the reasons for the company's collapse are still under discussion. Apart from financial, weather and social factors, the lack of company preparation and improper management are also mentioned. The aim of this article is to introduce the mistakes of 'Thomas Cook' agency and to emphasize the importance of relationships, ties, crisis management and risk management. The literature query and the netographic analysis were used in this case study, and the results indicated the direct reason for the collapse of the travel agency, which means its stagnation and superficial ties without security in management. The conclusions highlight important components of travel agency management and relations, which may prove to be the basis for future research.

Translated by Natalia Siwik 